\title{
Hubungan antara tajam penglihatan dengan derajat non-proliferative diabetic retinopathy pada pasien diabetes melitus tipe 2
}

\author{
Ade J. Nursalim \\ Vera Sumual \\ KSM Mata RSUP Prof. Dr. R. D. Kandou Manado \\ Email: dr.adejn@gmail.com
}

\begin{abstract}
This study aimed to determine the relationship between visual acuity and degree of Non Proliverative Diabetic Retinopathy (NPDR) in patients with type 2 diabetes mellitus (T2DM). This study was conducted in Retina Subdivision Ophthalmology Department Prof. Dr. R. D. Kandou Hospital, Manado, North Sulawesi, Indonesia. Samples were 354 eyes. Visual acuity examination was performed on all patients diagnosed with NPDR by using a Snellen chart at 6 meters distance. NPDR degree was graded according to the International Clinical Diabetic Retinopathy Disease Severity Scale of the American Academy of Ophthalmology. Correlation analysis between visual acuity and the NPDR degree was done by using Kruskal Wallis test which showed a $P$ value of 0.185 (>0.05). Conclusion: Visual acuity had no significant relationship to the degree of NPDR.
\end{abstract}

Keywords: visual acuity, NPDR, T2DM

\begin{abstract}
Abstrak: Penelitian ini bertujuan untuk mengetahui hubungan antara tajam penglihatan dengan derajat Non Proliverative Diabetic Retinopathy (NPDR) pada penyandang diabetes melitus tipe 2 (DMT2). Penelitian ini dilakukan di Poliklinik Mata Subdivisi Retina RSUP Prof. Dr. R. D. Kandou Manado, Provinsi Sulawesi Utara, Indonesia. Sampel penelitian berjumlah 354 mata. Pemeriksaan visus dilakukan pada semua pasien yang terdiagnosis NPDR dengan menggunakan Snellen chart pada jarak 6 meter. Penilaian derajat NPDR berdasarkan International Clinical Diabetic Retinopathy Disease Severity Scale dari American Academy of Ophthalmology. Analisis hubungan visus dengan derajat NPDR dilakukan dengan uji statistik Kruskal Wallis yang menunjukkan nilai $P=0,185(>0,05)$. Simpulan: Tidak terdapat hubungan bermakna antara tajam penglihatan (visus) dan derajat NPDR.
\end{abstract}

Kata kunci: visus, NPDR, DMT2

Retinopati diabetik merupakan penyebab utama kebutaan di dunia pada usia produktif. ${ }^{1} \quad$ Sebuah studi epidemilogi menemukan $34,6 \%$ dari penderita diabetes melitus (DM) terkena non proliverative diabetic retinopathy (NPDR) dan 6,96\% terkena proliverative diabetic retinopathy (PDR). ${ }^{2}$ Provinsi Sulawesi Utara memiliki angka prevalensi DM tertinggi ketiga di Indonesia yaitu sebesar 2,4\% dibandingkan provinsi DI Yogyakarta $(2,6 \%)$ di urutan pertama dan provinsi DKI Jakarta $(2,5 \%)$ di urutan kedua. Meski berada di urutan ketiga, angka ini jauh lebih tinggi daripada rata-rata prevalensi DM untuk seluruh provinsi di Indonesia yaitu sebesar $1,5 \% .^{3}$ Besarnya jumlah penderita DM juga berakibat besarnya jumlah penderita retinopati diabetik. Diagnosis dan penanganan segera dari retinopati diabetik memberikan prognosis yang baik bagi pasien dan dapat menurunkan prevalensi penyebab kebutaan pada usia produktif. ${ }^{4}$

Retinopati diabetik merupakan kelainan pada retina mata yang disebabkan oleh komplikasi DM. Kondisi hiper- 
glikemik selama jangka waktu tertentu menyebabkan perubahan fisiologik yang mengakibatkan kerusakan endotel. Kerusakan ini dapat berupa hilangnya perisit dan penebalan membran basalis. Perubahan ini menuju ke penyumbatan kapiler dan hilangnya perfusi retina serta kerusakan fungsi sawar dari endotel yang berakibat kebocoran serum dan edema retina. 5

Berdasarkan keparahannya, retinopati diabetes dibagi menjadi dua yaitu non proliverative diabetic retinopathy (NPDR) dan proliverative diabetic retinopathy (PDR). Pada NPDR ditemukan adanya mikroaneurisma, kebocoran pembuluh darah, serta keluarnya bahan lemak dari pembuluh darah. Terdapat tiga klasifikasi tingkat keparahan dari NPDR yaitu: mild (ditandai adanya mikroaneurisma atau satu perdarahan intraretinal); moderate (ditandai dengan mikroaneurisma atau perdarahan intraretinal yang lebih parah atau terdapat intraretinal microvascular abnormalities (IRMA) yang ringan); dan severe (ditandai adanya mikroaneurisma atau perdarahan di empat kuadran atau terdapat venous beading pada minimal dua kuadran atau terdapat IRMA pada salah satu kuadran). ${ }^{6}$

Konsil Kedokteran Indonesia dalam standar kompetensi dokter Indonesia menggolongkan penyakit DM ke dalam kompetensi 4 a yang berarti lulusan dokter mampu membuat diagnosis klinik dan melakukan penatalaksanaan penyakit tersebut secara mandiri dan tuntas. Kompetensi 4a juga berarti kemampuan ini seharusnya sudah dicapai pada saat lulus dokter meski belum mengikuti internship atau pendidikan kedokteran berkelanjutan (PKB). Berbeda halnya dengan retinopati diabetik dimana dokter umum diharapkan dapat melakukan diagnosis dan kemudian merujuk (kompetensi 2). ${ }^{7} \quad$ Standar kompetensi ini akan menghadapkan dokter umum sebagai lini pertama pelayanan kesehatan untuk mendiagnosis dan melakukan penatalaksanaan hingga tuntas untuk DM. Selain itu, dokter umum juga diharapkan dapat mendiagnosis retinopati diabetik dan kemudian merujuk pasien tersebut.

Pemeriksaan oftalmologis yang mudah dilakukan di pelayanan kesehatan primer salah satunya ialah pemeriksaan tajam penglihatan (visus). Penelitian ini bertujuan untuk mengetahui hubungan antara tajam penglihatan dengan derajat NPDR pada penderita DM tipe 2. (DMT2)

\section{METODE PENELITIAN}

Penelitian ini dilakukan di RSUP Prof. Dr. R. D. Kandou, Manado, Provinsi Sulawesi Utara, Indonesia. Penelitian dilakukan mulai bulan Maret 2015 hingga Maret 2016 dengan besar sampel sejumlah 354 mata. Subyek penelitian ialah pasien NPDR yang berkunjung ke Poliklinik Mata Subdivisi Retina di RSUP Prof. Dr. R. D. Kandou. Kriteria inklusi ialah pasien dengan diagnosis NPDR sesuai dengan kriteria diagnosis dari American Academy of Ophthalmology dan berusia lebih dari 18 tahun. Kriteria eksklusi ialah terdapat penyakit penyerta lain selain DM dan NPDR.

Pemeriksaan visus dilakukan pada semua pasien yang terdiagnosis NPDR dengan menggunakan Snellen chart pada jarak 6 meter. Pemeriksaan visus dilakukan oleh refraksionis dan penilaian NPDR dilakukan oleh dokter spesialis mata konsultan vitreoretina. Penilaian derajat NPDR menggunakan pembagian berdasarkan International Clinical Diabetic Retinopathy Disease Severity Scale dari American Academy of Ophthalmology. ${ }^{6}$

Data karakteristik hasil penelitian dideskripsikan dalam bentuk tabel. Analsis hubungan visus dengan derajat NPDR dilakukan dengan uji statistik Kruskal Wallis.

\section{HASIL PENELITIAN}

Tabel 1 menunjukkan bahwa usia terbanyak subyek penelitian ialah 51-60 tahun $(41,8 \%)$ dengan nilai rerata usia 56 tahun (SE 0,47 tahun). Usia minimum lebih dari 32 tahun dan usia maksimum 81 tahun. Jenis kelamin terbanyak ialah perempuan 
sebanyak 195 pasien $(55,1 \%)$ sedangkan jenis kelamin laki-laki sebanyak 159 pasien $(44,9 \%)$.

Kelompok NPDR mild memiliki rerata visus 0,45 (SE 0,03); kelompok NPDR moderate memiliki rerata visus 0,40 (SE 0,03), dan kelompok NPDR severe memiliki rerata visus 0,38 (SE 0,03 ).

Tabel 1. Karakteristik subjek penelitian

\begin{tabular}{|c|c|c|}
\hline Karakteristik & Jumlah & Persentase $(\%)$ \\
\hline \multicolumn{3}{|l|}{ Usia } \\
\hline $30-40$ & 10 & 2,9 \\
\hline $41-50$ & 80 & 22,7 \\
\hline $51-60$ & 148 & 41,8 \\
\hline$>60$ & 116 & 32,7 \\
\hline Mean & 56,19 & \\
\hline Std. Error of Mean & 0,47 & \\
\hline Median & 56 & \\
\hline Modus & 53 & \\
\hline Std. Deviation & 8,80 & \\
\hline Minimum & 32 & \\
\hline Maksimum & 81 & \\
\hline \multicolumn{3}{|l|}{ Jenis kelamin } \\
\hline Laki - laki & 159 & 44,9 \\
\hline Perempuan & 195 & 55,1 \\
\hline \multicolumn{3}{|c|}{ Visus kelompok NPDR Mild } \\
\hline Mean & 0,45 & \\
\hline Std. Error of Mean & 0,03 & \\
\hline Median & 0,4 & \\
\hline Modus & 0,67 & \\
\hline Std. Deviation & 0,32 & \\
\hline \multicolumn{3}{|c|}{ Visus kelompok NPDR Moderate } \\
\hline Mean & 0,40 & \\
\hline Std. Error of Mean & 0,03 & \\
\hline Median & 0,3 & \\
\hline Modus & 0,67 & \\
\hline Std. Deviation & 0,31 & \\
\hline \multicolumn{3}{|c|}{ Visus kelompok NPDR Severe } \\
\hline Mean & 0,38 & \\
\hline Std. Error of Mean & 0,03 & \\
\hline Median & 0,3 & \\
\hline Modus & 0,67 & \\
\hline Std. Deviation & 0,29 & \\
\hline \multicolumn{3}{|c|}{ Jumlah pasien per derajat NPDR } \\
\hline Mild & 124 & 35 \\
\hline Moderate & 104 & 29,4 \\
\hline Severe & 126 & 35,6 \\
\hline
\end{tabular}


Jumlah pasien NPDR terbanyak ialah derajat severe sebanyak 126 pasien $(35,6 \%)$, diikuti oleh derajat mild sebanyak 124 pasien $(35 \%)$, dan moderate sebanyak 104 pasien $(29,4 \%)$.

Hasil uji Kruskal Wallis menunjukkan hubungan yang tidak bermakna antara tajam penglihatan (visus) dengan derajat NPDR $(P=0,185>0,05)($ Tabel 2$)$.

Tabel 2. Uji Kruskal Wallis untuk hubungan visus dengan derajat NPDR

\begin{tabular}{lc}
\hline & Visus \\
\hline Chi-Square & 3,379 \\
df & 2 \\
Asymp. Sig. & 0,185 \\
\hline
\end{tabular}

\section{BAHASAN}

Hasil penelitian ini menunjukkan bahwa jenis kelamin terbanyak ialah jenis kelamin perempuan $(55,1 \%)$. Proporsi ini sesuai dengan proporsi data penderita DMT2 dari Quintiles Electronic Medical Record Database pada Juli 2014 hingga Juni 2015. Data tersebut menunjukkan bahwa dari 1.389.016 pasien DMT2, sebanyak $53 \%$ berjenis kelamin perempuan. ${ }^{8}$ Proporsi ini juga didukung oleh temuan di Sudan dimana proporsi jenis kelamin perempuan lebih banyak daripada jenis kelamin laki-laki, ${ }^{9}$ namun hal ini tidak sesuai dengan temuan di Irlandia dimana $57 \%$ pasien retinopati diabetik berjenis kelamin laki-laki. ${ }^{10}$

Hasil penelitian menunjukkan terdapat perbedaan rerata visus tiap kelompok derajat NPDR. Visus untuk kelompok NPDR mild, moderate dan severe secara berturut-turut 0,45 (SE 0,03), 0,40 (SE 0,03), dan 0,38 (SE 0,03). Perbedaan ini menunjukkan bahwa semakin tinggi derajat NPDR semakin buruk visus meskipun visus terbanyak untuk ketiga kelompok sama yaitu 0,67 .

Pasien NPDR pada penelitian ini sebagian besar berada pada derajat severe yaitu sebanyak $126(35,6 \%)$ diikuti derajat mild pada urutan kedua sebanyak 124 (35\%). Berbeda dengan temuan pada sebuah penelitian di Saudi Arabia yang meloprkan sebagian besar NPDR memiliki derajat mild $(57,5 \%)$ dan paling sedikit pada derajat severe $(11 \%) .{ }^{11}$ Penelitian ini tidak mengumpulkan data durasi penderita DMT2 sehingga sulit diketahui durasi perjalanan penyakit NPDR yang diderita oleh pasien. Kurangnya kebiasaan melakukan pemeriksaan umum berkala (general checkup) mungkin berhubungan dengan kurangnya pengetahuan pasien mengenai keadaan DM yang dideritanya. Retinopati diabetik sebagai komplikasi dari DM memerlukan diagnosis dini dan penanganan segera untuk menghindari komplikasi yang lebih lanjut. Studi epidemiologis Wisconsin mengenai retinopati diabetik menemukan bahwa setelah 20 tahun terkena DMT2, sekitar $60 \%$ pasien mengalami retinopati diabetik. ${ }^{5}$ Studi epidemiologis ini menekankan pentingnya diagnosis dini dan penatalaksaan segera dari retinopati diabetik.

Hasil uji statistik Kruskal Wallis menunjukkan hubungan yang tidak bermakna antara tajam penglihatan (visus) dengan derajat NPDR $(P 0,185>0,005)$. Tidak bermaknanya hubungan antara visus dengan derajat NPDR kemungkinan disebabkan oleh perbedaan lokasi retinopati pada pasien. AAO dalam BCSC retina menuliskan kondisi-kondisi yang berhubungan dengan kehilangan penglihatan pada pasien retinopati diabetik antara lain: kebocoran kapiler (edema makula), penyumbatan kapiler (iskemia makula, papilopati diabetik) dan sekuele dari neovaskularisasi yang disebabkan iskemia (perdarahan vitreus, traction retinal detachment dan glaukoma neovaskuler). ${ }^{5}$ Kondisi-kondisi ini memiliki lokasi utama lesi di makula, papil, vitreus, dan retina.

Bila ditinjau dari sistem penilaian derajat NPDR, sistem penilaian yang digunakan dalam penelitian ini didasarkan pada pembagian oleh International Clinical Diabetic Retinopathy Disease Severity Scale dari American Academy of Ophthalmology. Pembagian derajat NPDR 
ini memungkinkan terjadinya kondisikondisi kehilangan penglihatan seperti yang telah disebutkan di atas untuk ketiga derajat (mild, moderate, dan severe). ${ }^{6}$ Derajat severe untuk NPDR yang ditandai dengan kelainan di empat kuadran sangat mungkin mengenai makula, papil, dan vitreus. Penelitian ini menemukan perbedaan visus pada ketiga derajat NPDR dengan kecenderungan semakin berat derajat NPDR semakin buruk visus dari penderita meskipun dengan uji statistik di dapatkan tidak bermakna.

\section{SIMPULAN}

Tidak terdapat hubungan bermakna antara tajam penglihatan (visus) dan derajat NPDR meskipun dengan kelainan pada empat kuadran pada derajat severe NPDR.

\section{SARAN}

Temuan ini mengimplikasikan bahwa dokter di lini petama pelayanan kesehatan perlu merujuk pasien yang terdiagnosis DMT2 ke spesialis mata untuk menghindari komplikasi NPDR meskipun visus pasien masih relatif baik. Diagnosis dan penanganan NPDR yang cepat dan baik akan memberikan prognosis yang lebih baik.

\section{DAFTAR PUSTAKA}

1. Ajlan RS, Silva PS, Sun JK. Vascular endothelial growth factor and diabetic retinal disease. Semin Ophthalmol. 2016;31(1-2):40-8. Doi: 10.3109/08820538.2015.1114833.

2. Yau JWY, Rogers SL, Kawasaki R, Lamoureux EL, Kowalski JW, Bek $\mathbf{T}$, et al. Global prevalence and major risk factors of diabetic retinopathy. Diabetes care. 2012;35(3):556-64.

3. Hasil Riset Kesehatan Dasar (Riskesdas). Jakarta: Badan Penelitian dan Pengembangan Kesehatan, Kementerian Kesehatan RI; 2013. [cited 2016 May 25]. Available from: www.depkes.go.id/resources/download /general/Hasil\%20Riskesdas\%202013 .pdf.

4. Olafsdottir E, Andersson DK, Dedorsson I, Svärdsudd K, Jansson SP, Stefánsson E. Early detection of type 2 diabetes mellitus and screening for retinopathy are associated with reduced prevalence and severity of retinopathy. Acta Ophthalmol. 2016: 94:232-9.

5. American Academy of Ophthalmology. Retinal vascular disease: Diabetic retinopathy. In: Retina and Vitreous; Basic and Clinical Science Course. Italy: AAO, 2014; p. 89-112.

6. Wilkinson CP, Ferris FL 3rd, Klein RE, Lee PP, Agardh CD, Davis M, et. al. Proposed international clinical diabetic retinopathy and diabetic macular edema disease severity scales. Ophthalmology. 2003;110(9): 1677-82.

7. Standar Kompetensi Dokter Indonesia. Jakarta Pusat: Konsil Kedokteran Indonesia, 2012; p. 38, 51.

8. Iglay K, Hannachi H, Howie PJ, Xu J, Li X, Engel SS, Moore LM, Rajpathak S. Prevalence and co-prevalence of comorbidities among patients with type 2 diabetes mellitus. Curr Med Res Opin. 2016:1-10. Doi:10.1185/03007995.2016.1168291

9. Ahmed AMB, Yagoub TE, Alla HMK, Musa NO, Ali MA. Causes and risk factors contributed and responsible for prevalence and incidence of retinopathy in Al- Walidain Hospital in Omdurman - Sudan. Imperial J Interdiscip Res. 2016;2(5);831-4.

10. Hugh SM, Buckley C, Murphy K, Doherty S, O'keeffe G, Alade J, et. al. Quality-assured screening for diabetic retinopathy delivered in primary care in Ireland: an observational study. Br J Gen Pract. 2013;63(607); e134-e140.

11. Ahmed RA, Khalil SN, Al-Qahtani MA. Diabetic retinopathy and the associated risk factors in diabetes type 2 patients in Abha, Saudi Arabia. J Fam Community Med. 2016;23:18-24 